\title{
Making the grade: infrastructural semiotics and derivative market outcomes on the Chicago Board of Trade and New Orleans Cotton Exchange, 1856-1909
}

\author{
David Pinzur \\ University of California, San Diego
}

\begin{abstract}
This article contributes to a socio-technical analysis of derivatives by offering an infrastructural explanation of divergent outcomes on two early American futures markets. It takes as the starting point of analysis the classification systems by which these futures markets were constitutively linked to underlying markets in agricultural commodities. Despite the formal similarity of these systems, their contrasting implementation-i.e., how grading was accomplished and integrated into practice - produced classifications with dissimilar semiotic qualities. This semiotic distinction is shown to have promoted divergent economic behaviors and outcomes on the two markets: high-risk speculation and volatility on the Chicago Board of Trade, low-risk hedging and stability on the New Orleans Cotton Exchange. The article thus argues that treating classifications in their semiotic capacity yields an analysis that can connect foundational infrastructures and market-level outcomes in meaningful, non-deterministic ways.
\end{abstract}

Keywords: derivatives; infrastructure; classification; semiotics; social studies of finance; Chicago Board of Trade; New Orleans Cotton Exchange

\section{Introduction}

Economic sociologists have taken two approaches to studying derivative markets. On the one hand, they have highlighted their similarities with other types of markets, demonstrating that culture (Abolafia 1996), network relations (Baker 1984), and material framing devices (Arnoldi 2006; MacKenzie 2006; Zaloom 2006) influence behavior on derivative markets much as they do elsewhere. On the other hand, scholars have analyzed derivatives in terms of their unique features, most notably the fact that their value is a function of the price of an underlying entity. From this perspective, scholars have asked pointed questions about the distinct features of derivatives: How is their connection to underlying entities constituted by the actions of diverse 
individuals and organizations (Millo 2007)? What material processes produce the seeming abstractness of derivatives (MacKenzie 2007; Maurer 2002)? How do the calculative, risk management practices at the heart of derivative trading alter our understanding of money's capabilities (Pryke \& Allen 2000)?

This article contributes to the latter stream of research through a comparative historical study of the creation of futures markets on the Chicago Board of Trade (CBOT) and the New Orleans Cotton Exchange (NOCE) between 1856 and 1909. ${ }^{1}$ Specifically, it analyzes these simple derivative markets in terms of the systems of classification by which they were constitutively linked to an underlying primary market (Cronon 1991). Classification systems were significant in both primary (or, 'spot') markets, where they provided a guide to the quality of agricultural commodities-wheat in Chicago and cotton in New Orleans-and derivative (futures) markets, where they provided standard classes that could be traded at high volume (see, e.g., Santos 2002). The question this article asks is: How did these classification systems influence behaviors and outcomes on the derivative markets? Specifically, were there differences in the form or implementation of the systems that can account for the markets' wide divergence in price volatility over the fifty-year period of my research (see Figures 1 and 2; also, more generally, Bouilly 1976; Cronon 1991; Lurie 1979; Markham 2002)?

\section{[FIGURES 1 AND 2 ABOUT HERE.]}

To preview my answer to these questions: I find that these exchanges' classification infrastructures (Bowker 1994; Star \& Ruhleder 1996), while formally similar, operated in distinct ways. CBOT graded commodities upon their entrance into store using a single, independent party, and permanently inscribed grades on receipts; NOCE only supervised the 
grading process, which took place in an antagonistic negotiation between buyer and seller at the point of exchange, and produced classifications that were only temporary appellations. ${ }^{2}$ These differences led classifications on each exchange to differ along two semiotic dimensions: grades on CBOT failed to index the physical qualities of the commodity to the degree of those on NOCE; grades on CBOT established a permanent relation between their indexical and symbolic functions, while on NOCE this relation was continually negotiated. I then draw a theoretical connection between this semiotic divergence and three distinct types of derivative market trades — speculation, hedging, and cornering — arguing that the semiotic qualities of classifications on CBOT promoted high-risk speculation and corners, while those on NOCE fostered low-risk hedging. In sum, I trace a line of influence from the classifying practices at the root of these derivative markets through to the contrasting levels of volatility seen on each. The article thus outlines a general theory of how infrastructure, through its semiotic characteristics, can non-deterministically influence system-level dynamics and outcomes.

\section{Classification and communication}

This article conceptualizes classification systems as market infrastructures (Pardo-Guerra 2013). Infrastructures are socio-technical devices that support action locally while enabling coordination globally (Bowker 1994; Star \& Lampland 2009; Star \& Ruhleder 1996). They undergird large-scale technical systems (Hughes 1987) by harmonizing multiple, independent technologies and communities of practice around a single, common standard (Barry 2001; Bijker, Hughes \& Pinch 1987; Edwards, Bowker, Jackson \& Williams 2009). When infrastructures work as intended they transparently support everyday action, becoming visible 
and contested only upon breakdown. Shared classification schemes are foundational infrastructural components in that they underlie, support, and coordinate action across multiple markets (Bowker \& Star 1999).

Scholars have argued that infrastructures work in part because they facilitate communication among the groups that use them. Star (2002: 109), for example, calls infrastructures 'communicative tools'; Bowker \& Star (1999: 286) argue that classification systems allow people to 'communicate across the boundaries of disparate communities'; and Edwards (2010: 18) notes that a classification infrastructure is, among other things, a 'communication ... web with both social and technical dimensions'. These scholars have tended to assume that communication occurs unproblematically once two infrastructures have been 'plugged into' one another via a common set of standards (Bowker \& Star 1999: 35; see also Star \& Lampland 2009; Star \& Ruhleder 1996). The single classification scheme establishes a shared ontology across settings, which serves as a common language allowing actors to reference the same types of objects, processes, and relations (Espeland \& Stevens 1998).

Yet, while a shared ontology may make communication possible, it tells us nothing about the quality of communication that takes place. The issue of 'work arounds' illustrates this point. Much research has shown that shared classifications and standards fail to create uniformity of practice across environments (Barry 2001; Bowker \& Star 1999; Edwards, et al. 2009; Millerand $\&$ Bowker 2009). Familiar ways of working are retained without change, and simply labeled in accordance with a new classification scheme for bureaucratic or symbolic reasons (Meyer \& Rowan 1977). The prevalence of work arounds suggests that a shared classificatory language does not guarantee uniform or reliable communication. Rather, understanding classification 
infrastructures as 'communicative tools' requires explicitly theorizing their character not as ontological, but as semiotic, entities.

Theorizing classifications as semiotic entities requires a shift in focus from the construction of classification schemes (Star 2002) to the practice of classifying itself (Hatherly, Leung \& MacKenzie 2008). Prior research has treated the former as critical: it is the moment when partisans battle to establish the contours of the system and set into place an ontology with far-reaching political consequences (Cronon 1991; Espeland \& Sauder 2007; Foucault 1982; Miller \& O’Leary 1987; Miller \& Rose 1990). But it is in the latter moment—classifying as a practical act - that classifications acquire their semiotic content. As this process changes, so too are the meanings of classifications altered (Barnes 1983; Bloor 1997; Wittgenstein 1967). The significance of even the most basic economic classifications, such as 'profit' and 'loss', are continually reshaped by the evolution of classifying practices (Hatherly, Leung \& MacKenzie 2008).

Classifying practices are influenced by a number of social and material factors, as seen in studies of arbitrage, financial analysis, and accounting, all of which involve classification as a central practice. In arbitrage, the act of classifying is shaped by the materiality of the trading room (Beunza \& Stark 2004), the presence of competing heterogeneous principles of valuation (Stark 2009), and the hierarchical relations of the firm (Beunza, Hardie \& MacKenzie 2006). Among securities analysts, the process of classifying stocks is constrained by analysts' need to maintain legitimacy among investors (Zuckerman 1999) and tethered to broader frames of valuation (Beunza \& Garud 2007). Even accountants' classifying practices, which occur within a well-defined, institutionalized classification scheme, are influenced by cultural, technical and 
institutional factors (Hatherly, Leung \& MacKenzie 2008). These factors shape how classification occurs and what classifications signify.

The classifying process shapes not only what classifications signify, but how they signify. I understand the issue of how signification occurs, following other pragmatist-inspired work (Gross 2009; Muniesa 2007), in terms of Peirce's trichotomy of semiotic modes-icon, index, and symbol. ${ }^{3}$ These modes can result from distinct practices of classifying. Muniesa (2007) demonstrates that different procedures for producing closing prices on the Paris Bourse and the Bolsa de Madrid created prices that differed in their primary semiotic mode. Simply using the last trade of the day produced a good index, but failed symbolically; making an average of trades in the last five minutes produced a good icon, but a poor index; utilizing an algorithmic auction produced a fairly good index, combined with a strong symbol. Lampland (2010) notes that bookkeeping practices among farmers in Stalinist Hungary used 'false numbers' that acted not as indexes, but as icons representing the implementation of rational, written management practices. Similarly, Lea \& Pholeros (2010) show how conditions of work led government contractors building houses in Australia to carelessly complete government checklists and forms, producing documents that served as icons of work practice rather than indexes of building quality as intended.

These different semiotic modes can in turn promote divergent behaviors on the market. Muniesa (2007) argues that the closure call auction algorithm produced a closing price that, due to its low indexicality, was difficult to manipulate. Thanks to the character of the sign produced, market manipulation was 'pragmatically calibrated' and 'rendered costly' (Muniesa 2007: 388). Similar analyses of semiotic character and market behavior have been made regarding the representation of prices. The stock ticker, for example, introduced a smooth temporal structure to 
the market, which enabled actors to make price variations an object of symbolic interpretation (Preda 2006). Screen-based displays enable traders to conceptualize the market in new ways, e.g., as intrinsically dynamic and processual (Knorr-Cetina \& Grimpe 2008) or as autonomous from the individuals who comprise it (Zaloom 2004). The changed semiotic character of prices in their new forms open up new ways of thinking and acting in the market.

I argue that we can exploit this linkage between semiotic mode and market behavior to understand not just particular trades or general perspectives, but also market-level dynamics and outcomes. Scaling up analysis to the market level requires the development of a method of accounting for the performance of a sign in its various semiotic modes: I refer to this property as semiotic 'fidelity'. Fidelity shapes the viability of economic actions taken on the basis of any particular semiotic mode: all else being equal, behaviors based on a high-fidelity semiotic mode will have better outcomes than those based on low-fidelity modes. Thus, as the contours of fidelity emerge, an analysis of market-level dynamics becomes possible. This is not to suggest, in an evolutionary economic style, that actions taken on the basis of low-fidelity modes will disappear from the market altogether. Rather, I argue that the universe of signs and their fidelity act as limiting conditions, which probabilistically influence the prevalence of particular behaviors and their success (Wright, Levine \& Sober 1992).

Below, I analyze the impact of classifying practices and the resultant semiotic character of grades on market volatility at the Chicago Board of Trade and the New Orleans Cotton Exchange. This eschews an ontological analysis, which cannot illuminate the causes of the divergent market outcomes, in favor of an approach that highlights classifications' communicative functions. Focusing on fidelity and the relation of the indexical and symbolic components of the grades used on each exchange, I argue that these markets likely saw different 
levels of speculation and hedging, which impacted outcomes in the market as a whole. The analysis demonstrates the value of a semiotic approach as a non-deterministic method for linking foundational infrastructures with system-level outcomes and dynamics.

\section{Cases and data}

The Chicago Board of Trade (CBOT) and the New Orleans Cotton Exchange (NOCE) were broadly similar. Both were among the first American commodity exchanges and early adopters of organized futures trading: CBOT was established in 1848 and began trading futures in 1856, with the practice gaining popularity in the 1860s; NOCE was established in 1871 and featured futures trading from its founding, with the practice becoming widespread in 1880 . Both exchanges featured large spot markets in regionally-produced agricultural commodities in addition to their futures markets. Both exchanges were organized with an elected Board of Directors and a number of smaller, standing committees dedicated to critical topics, e.g., futures, information and statistics, and warehousing. Members paid dues in order to access the exchange floor, and many made trades both on their own account and on behalf of clients around the world. Neither exchange had any rules that put limits on speculation, nor which forbade manipulative acts such as cornering the futures market. ${ }^{5}$

The exchanges also used formally similar classification systems to link their spot and futures markets. CBOT, in 1860, after a few preliminary tries, settled on a grading scheme with three kinds of wheat—white winter wheat, red winter wheat, and spring wheat—and four gradations of quality — club, number 1 , number 2 , and rejected. This classification scheme was retained, with minor additions, throughout the period of study. Wheat was classified on the basis of its purity, cleanliness, dryness, weight, and plumpness of the berry (CBOT, Organizational 
Records). Cotton was considered along a similar number of dimensions: fiber strength, staple length, purity of lint, and color, as well as the general region where it was grown (Boyle 1934). While the range for each of these dimensions was wider for cotton than for wheat (e.g., the measure of 'purity' for white cotton was divided into nine separate classes, as opposed to the four used for wheat), the vast majority of cotton fell within a narrow band. Of the three regional types of cotton, 99 per cent of American cotton was of one type; of the many colors in the scale, 85-90 per cent of cotton was white or extra white; of the vast number of staple lengths recognized, 75-85 per cent of cotton was found within six lengths (Garside 1935). This suggests that, for the majority of instances, the formal classification systems used on the exchanges were roughly comparable. This broad formal similarity serves as the backdrop for my empirical analysis, which reveals significant differences in classifying practices across the exchanges. ${ }^{6}$

There were undoubtedly factors affecting volatility in these cases beyond classification practices. Research suggests that trade networks on NOCE were more tightly-knit than on CBOT, that $\mathrm{CBOT}$ was less willing to hand down harsh punishments for engaging in prohibited trades, and that CBOT simply had a more permissive attitude towards speculation than NOCE. A vast literature suggests that these could all be sources of market volatility (see, e.g., on networks, Biggart 2001; Burt 1992; Rauch \& Casella 2001; on institutions, Abolafia 1998; Greif 1989; Williamson 1981; on culture, DeGoede 2005; Fabian 1990). While I do not discount that these features might have impacted volatility, I do claim that their impact in these cases was smaller, and more mixed, than theory might lead us to expect. First, while NOCE did have a more tightlyknit network of traders, these dense network connections did not always serve to keep markets orderly and stable. New Orleans saw large corners in the spot market for cotton in 1825,1839 and 1842, years when the small, elite-based factorage system was at its peak (Bouilly 1976). 
Second, the effect of CBOT's unwillingness to punish members for making prohibited trades was likely negligible. The two most common prohibited acts were trading away from the floor or at off hours, and trading options. These two trades, though, had countervailing effects on the market, with the first increasing volatility and the latter dampening it. Finally, though speculation was celebrated in Chicago, it certainly was not absent or flatly discouraged in New Orleans. The antebellum cotton market was 'replete with speculative attempts to manipulate the price or corner the spot market' (Bouilly 1976: 13). NOCE members defended speculation using the same language of increased efficiency and risk management as did members of CBOT.

More importantly, even if these factors did have some impact on volatility, my analysis highlights a distinct causal component in addition. The arguments discussed above aim to show the direct influence of networks, institutions, or culture on market behavior. In contrast, I argue that classifying practices indirectly impacted behavior by establishing semiotic conditions that made volatility-producing behaviors, such as heavy speculation and running corners, more plausible and rational on CBOT, and less so on NOCE (Wright, Levine \& Sober 1992). This argument does not conflict with explanations positing direct influences on price volatility, but complements them: the analytic relation is one of infrastructure to structure.

The data for the article come primarily from the CBOT and NOCE archives. They include annual reports, organizational records, published books and pamphlets, correspondence and meeting minutes, as well as the records of the CBOT committees on grain, warehouses, inspection, and futures, and the NOCE committees on supervision and inspection, futures, classifications, and information and statistics. I supplemented this archival data with secondary histories of each exchange. 


\section{The Chicago Board of Trade}

The impetus for creating standardized grades of wheat on CBOT in 1856 was the desire among elevator owners for more efficient storage methods. Prior to this time, elevators would store each shipment of grain separately, a practice which left enormous amounts of unused space in warehouse bins (Lee 1938). A market-wide classification scheme enabled elevators to combine grain of the same grade from different sources, thereby maintaining the aggregate quality while achieving full storage capacity. As Cronon (1991) has noted, this system was predicated on certain physical qualities of wheat - its ability to flow along conveyor belts and mix with other shipments. (These qualities are not found in cotton, a point whose significance will be explored further below.)

In order to store wheat in this fashion, CBOT's grading infrastructure needed to operate in particular ways: (i) wheat had to be graded as it entered into store, so that it could be combined with other shipments of the same quality; (ii) since wheat was put into store precisely because there was not yet a buyer for it, grading could not occur through negotiation between buyer and seller, but needed to be done by a single, independent party; (iii) there needed to be a system of receipts that allowed owners to retrieve an amount and quality of wheat equivalent to what was originally put into store (see Table 1, below). Each of these practices contributed to shaping the semiotic character of the grade produced. The overall effect was to create grades with low indexical fidelity for producers and consumers in the spot market, while at the same time inscribing a permanent relation between their symbolic and indexical functions through the use of warehouse receipts.

[TABLE 1 ABOUT HERE.] 


\section{Grading upon entrance into store}

One consequence of classifying wheat as it entered into store was that any changes occurring within the warehouse - whether intentional adulteration or natural spoilage — were not incorporated into the grade. This damaged the grade's ability to index wheat's physical qualities. The suitability of wheat for processing and consumption thus remained uncertain, even after it had been graded.

Intentional adulteration of wheat by profit-seeking elevator owners was a common practice. Owners would dilute stored grain of a higher grade (e.g., \#1 wheat) with their own, lower quality grain (e.g., \#2 wheat), creating a mixture that barely stood above the threshold between the two. This made them an instant profit on their own wheat, the value of which had improved through mixing. Of course, the resulting mixture was of a very poor quality for its grade, a fact discovered once shipments had been made to millers. The practice was so widespread that Chicago wheat brought four to five cents less per bushel than similar grades from other cities, leading some unscrupulous dealers to rebrand their wheat with other locations in the name, e.g., Milwaukee Club, Amber Iowa, and Northwestern Club (Taylor 1917).

In addition to this purposeful adulteration, wheat would occasionally spoil while in store. This would create a mismatch between the actual quality of wheat in elevators and the presumed quality based on the assigned grade. Mechanisms for reporting this spoilage were inadequate. Elevators were required under Board rules to declare the presence of spoiled wheat immediately upon its discovery $(C B O T, O R)$, however, many delayed these announcements as long as

possible because of the accompanying financial losses (Lee 1938). CBOT also conducted annual warehouse inspections, but, being infrequent, this brought to light only a few cases of spoilage 
(CBOT, Committee Records). The grain elevator thus remained a 'black box' to those in the trade, and the physical condition of grain a topic of rumour rather than knowledge.

\section{Single-party grading}

Since wheat needed to be graded before a buyer was found, the traditional method for determining quality — negotiation between buyer and seller-was not possible. CBOT thus had to place grading duties in the hands of a single, impartial group. But finding, or creating, this group proved difficult. The problems stemming from this single-party system contributed to grades being an unreliable index of wheat's physical qualities.

Initially, the Board sought to keep grading power in private hands. At the founding of the system, elevators themselves graded the incoming wheat; three years in, the Board of Trade took over. Both of these attempts were plagued by moral hazard. In the first instance, warehouses would inflate their grades in order to attract more grain into store and increase profits (Lee 1938). In the latter, inspectors faced a conflict of interest. Since Board rules did not prohibit them from dealing in the very wheat they inspected, many found it profitable to inflate grades or collude with elevator owners to their mutual benefit. The group of corrupt inspectors was not insignificant or peripheral: in January 1871, the Board's chief grain inspector was suspended, following his involvement in a grading scandal (Taylor 1917).

Following this scandal, in the spring of 1871, the state assumed control over inspection and classification. Power was vested with the newly created Illinois Railroad and Warehouse Commission (RWC), which hired a team of inspectors forbidden from taking any financial interest in the grain trade. Yet, even in the hands of the state, classification remained inaccurate. These continued inaccuracies stemmed not from any moral hazard, but from a second challenge 
of single-party grading: the need for expertise. The state did not require inspectors to pass an examination or show any special familiarity with the grain trade, and resisted the Board's repeated calls to place inspector positions under Civil Service Rules (CBOT: OR). CBOT charged that this was the result of grain inspection becoming part of the political machine of Illinois, with President William T. Baker, in 1900, caustically noting that, 'zeal in partisan campaign work does not qualify men for work as inspectors' (CBOT, BD: unnumbered page). This absence of expertise resulted in poor and uneven grading. Even when inspectors did have the necessary expertise, harsh working conditions made accurate, consistent grading difficult. Inspectors graded outdoors, not infrequently in the rain and cold, under pressure to move train traffic quickly through the elevators (Lee 1938).

All of these features of the single-party grading system made it difficult to ensure the fidelity of grades in the spot market. By 1900, many eastern buyers would accept the delivery of wheat from Chicago only after having their own private inspectors ensure its quality, and European exchanges were threatening to stop accepting Illinois inspection certificates altogether (CBOT: Board of Directors records; Committee records; Executive office records; OR). State inspection became so discredited that, according to Board president W.S. Warren in 1901, Chicago certificates, 'were not worth the paper they were printed on' (CBOT, Annual Report, 1901: unnumbered page).

Warehouse receipts

The final consequential feature of CBOT's classifying practice was the production of warehouse receipts. A receipt entitled its holder to a particular class of wheat housed in a particular elevator. Traders could settle deals by exchanging receipts rather than physically delivering the wheat itself. In receipts, CBOT created a material tool that permanently linked the 
grade's use as a symbol in the futures market, with its use as an index in the spot market. When this relation drifted apart in practice, the information found on receipts became an unreliable guide to the actual supply of wheat in the city's elevators.

As discussed above, maintaining the indexical relation between the grade inscribed on a receipt and the wheat it would call forth was not a simple task: wheat would spoil in store, while the receipts that represented it continued to circulate unchanged; grades on receipts would fail to accurately describe wheat's physical qualities, due to mixing, manipulation, or human error. Additionally, elevators were known to produce fraudulent receipts. They would sell these fake receipts when wheat prices were high, such as during a corner or other speculative mania, then buy them back when prices had dropped. As long as they bought the same quantity that was originally sold, there would be no outstanding claims for wheat they did not actually hold (Goldstein 1928; Taylor 1917). Rumours of such forgeries were common throughout the 1860s and substantiated by the discovery of fraud at two major elevators in 1872 (Taylor 1917). In both cases, the fraud was only discovered under extraordinary circumstances, suggesting that many other forgeries went undetected. ${ }^{7}$ Thus, while receipts were formally indexical market devices, the difficulty of maintaining this indexicality in practice made them of uncertain use to spot market buyers.

These findings show that the material features of wheat, as well as the political and organizational environment of the grain trade, influenced how CBOT's classification infrastructure was put into practice. The particular ways in which these practices-grading wheat as it entered into store, vesting grading authority in a single party, and making receipts that stood for grain in store - occurred resulted in grades that operated at a low indexical fidelity and were 
permanently linked in their symbolic and indexical functions through the device of a warehouse receipt.

\section{The New Orleans Cotton Exchange}

As with CBOT, the practical implementation of NOCE's classification infrastructure was shaped by the material qualities of the crop and its processing. Cotton came to New Orleans in sticky, condensed, 400-pound bales that, unlike carloads of wheat, could not flow or mix. Bales were not stored in bins that could be more or less full, but stacked one atop another (Garside 1935). For warehouse owners these physical differences meant that there was no possible way to reap profit by combining shipments from multiple sources. As a result — and unlike on CBOTNOCE did not need to create new groups or implement new methods in order to make their classification system operational. In fact, the system they used for futures trading had been in place on the spot market for decades (Sherman 1934).

Reflecting these material differences, NOCE's classifying practices differed from CBOT's on each dimension mentioned above: (i) cotton was graded not upon entry into store, but only at the point of exchange; (ii) grading was an antagonistic process, wherein quality was negotiated between buyers and sellers; (iii) since cotton retained its integrity throughout the storage process receipts entitled the holder to specific bales, obviating the need for grades to be

specified on the receipt (see Table 1, above). Overall, this implementation created classifications that had high indexical fidelity, but which only temporarily aligned grades in their symbolic and indexical functions.

\section{Grading at exchange}


As opposed to wheat, which was graded as it entered into store, cotton was graded only at the point of exchange. Both buyer and seller would hire expert cotton classers to represent their interests. These classers would meet at the warehouse where cotton was held to sample the bales and negotiate their grades. One consequence of grading at exchange was that a seller could not be certain of his cotton's value prior to sale. This stands in contrast to CBOT's system, which assigned a permanent grade to wheat as it entered into store.

The uncertainty of the grading process was reflected in the workings of the futures market. Since it was impossible to know prior to exchange what grade a bale of cotton would bring, NOCE futures contracts could not demand the exclusive delivery of a single grade - for what would happen if classers decided that the cotton was actually of a lower or higher grade than that called for in the contract? To avoid this problem, NOCE futures contracts could be satisfied through the delivery of a range of grades, with an appropriate premium or discount on the contract price (NOCE, Annual Report). ${ }^{8}$ Additionally, there were no restrictions on delivery related to any other qualities of cotton (e.g., 'body', the degree to which fibers tended to adhere to each other, or 'staple length', the average length of fibers, qualities which were critical to spot dealers and spinners). This made the NOCE future a 'seller's contract', one in which the obligation to deliver could be easily met.

The fact that cotton was graded only upon exchange meant that grades were used on the futures market purely symbolically, and their indexical relation to cotton was only established at the point of exchange. This lack of a permanent connection between symbolic and indexical functions added uncertainty to transactions that spanned the futures and spot markets.

\section{Antagonistic grading}


Since classifying remained a private, antagonistic process, NOCE was freed to direct its organizational resources to the grade's maintenance as an index of quality and quantity. To this end, in 1876, NOCE established the departments of Supervision and Inspection. These departments documented the processing and handling of bales, ensuring a grade with high indexical fidelity for spot market actors.

Supervisors oversaw the preparation of bales in cotton presses and warehouses, recording the amount of loose cotton stored at each press as well as the weight of the samples taken by each party's classers (NOCE: $A R$ ). This prevented petty thieves or press owners from pilfering small amounts off of bales. Inspectors followed the cotton as it went from the warehouse to the levee, keeping books that noted whether cotton was taken on board a ship in wet or dry condition (and if wet, whether the cotton was received wet or became so by being exposed to rain or rolled through mud) and if a ship stored cotton on its deck, open to the elements (NOCE: AR;

Volumes). This information was available to all Exchange members and was regularly consulted when determining responsibility for cotton arriving out of condition (NOCE: AR; V). NOCE officials boasted that these departments 'added more to the reputation of New Orleans for care and attention to the produce intrusted [sic] to her merchants than any other measure ever before adopted' (NOCE, AR, 1881: 3). The oversight they provided ensured that cotton was not physically altered between its grading and its storage on a ship, producing a high-fidelity grade for spot market buyers.

\section{Temporary grades}

Since grading occurred each time cotton changed hands, it was possible for the same bale to be bought and sold at multiple grades over the course of its tenure in the city's warehouses. 
Classifications only temporarily brought the grade's symbolic and indexical functions into contact: NOCE had no equivalent of the warehouse receipt, which permanently linked these functions on CBOT. The fact that grades were only temporary introduced uncertainty into the connection between grades as symbols on the futures market and as indices on the spot market.

The possibility of fluctuations in grade added risk to any deal involving actual cotton. A trader might suffer a loss from buying at one grade and having to sell at a lower one, a possibility made more likely by the delicate nature of cotton classing (Garside 1935). ${ }^{9}$ Speculators and spot dealers related to this risk differently. Spot dealers used it to their benefit, buying cotton at a lower grade in small towns, where markets were less competitive, then selling at a higher grade in the city, or skillfully displaying samples to bring a higher grade (Boyle 1934; Garside 1935). Speculators, on the other hand, wished to avoid the risk of re-grading altogether. They lacked the spot dealers' familiarity with the cotton crop and had no relationship with interior markets. Hiring an expert classer was simply an additional expense with an uncertain payoff. Accordingly, they often would try to sell contracts prior to the call date if they thought the buyer would demand delivery, even selling at below market price if necessary (Garside 1935). Thus, despite being a 'seller's contract', speculators in futures were discouraged from handling actual cotton because of the cost and unpredictability of the grading process. The uncertain connection between grades as symbols and indices created a significant gap between spot and futures markets.

These findings show the influence of cotton's material features, as well as the organizational and economic environment, on the practical implementation of NOCE's classification infrastructure. Since there was no incentive to grade cotton as it entered into store, grading could continue in the traditional manner, as a private negotiation between parties. This 
freed NOCE to focus on maintaining the quality of underlying commodities, rather than assigning grades. Further, the connection between futures contracts and particular grades of cotton was not automated via receipts, as in CBOT, but mediated by expert cotton classers, such that grading remained both costly and uncertain. The combined effect of these features was to produce classifications with high indexical fidelity, but an unstable relation between their symbolic and indexical functions.

\section{Infrastructural semiotics and market outcomes}

These findings demonstrate that CBOT and NOCE differed significantly in how grades were assigned to commodities and integrated into practice. While CBOT graded wheat as it entered into store, used a single grading party, and inscribed grades permanently in warehouse receipts, NOCE graded cotton only upon exchange, in a two-party, antagonistic process, and produced merely temporary grades. This, in turn, impacted the semiotic content of the resulting classifications: CBOT produced a grade with a far lower indexical fidelity and a permanent relation between symbolic and indexical modes; NOCE produced a grade with high indexical fidelity, but an unpredictable connection between the symbolic and indexical.

In the following discussion, I show how these semiotic distinctions affected market-level outcomes. I do so by considering three distinct types of trades that took place on these futures markets, and the meaning that grades needed to convey in order for each to occur. The types of trades are: (i) speculation that occurred entirely within the futures market, and in which contracts were not settled by delivery of goods; (ii) hedging, which involved parallel transactions, one entirely within the futures market, the other entirely within the spot market; (iii) speculation that resulted in the delivery or receipt of goods in the spot market, often against the expectations or 
desires of traders. The first two types of trades formed the bulk of everyday trading on futures markets (United States Congress House Committee on Agriculture 1892). The final type was rare, but particularly significant for market stability because it was critical to the act of cornering the futures market (Cronon 1991; Ferris 1988). ${ }^{10}$ I argue that the divergent semiotic features of the grades produced on CBOT and NOCE made these types of trades more or less likely to occur on each exchange, promoting volatility in Chicago and stability in New Orleans. ${ }^{11}$

The first type of trade, speculation that was settled without delivery of goods, occurred entirely within the futures market. Traders would meet their contractual obligations not by delivering any real commodity (or receipts representing real commodities), but simply by paying or receiving the difference between the contract price and the spot market price. ${ }^{12}$ The grade only came into play in that it specified which commodity's market price was the object of the speculative bet. For the purposes of this type of trade, a futures contract for Colorado Red Wheat was essentially a bet on the price of the commodity being marketed as 'Colorado Red Wheat'the physical qualities represented by this label were inconsequential. Thus, speculation only required the classification system to produce viable symbols, or to act as a symbolic infrastructure.

Symbolic infrastructures can be understood as stable, logically coherent classification systems within which signs are meaningfully related - the details of how classifications are put into practice are unimportant. Both exchanges created symbolic infrastructures simply by establishing formal classification schemes in the rules of their organizations. Ontological approaches to classifications - inasmuch as they focus on the creation, expansion, and consequences of formal classifications schemes, rather than their implementation—study symbolic infrastructures (Barry 2000; Bowker \& Millerand 2009; Bowker \& Star 1999; 
Lampland \& Star 2009). This marks a clear limit to ontological analyses, which a semiotic approach moves beyond.

The second type of trade, hedging, used the futures market to insure a spot market position against adverse price movements. Traders took up a position in the futures market, which they generally settled by difference, while simultaneously buying or selling actual physical commodities in the spot market. In this way, any loss in the spot market (e.g., from the price of spot wheat dropping while looking for a buyer) would be offset by a gain in the futures market (e.g., from having sold wheat short and profiting from the price decline). Hedging thus involved making two trades that played out in parallel, one entirely within the futures market, the other entirely within the spot market.

The futures portion of a hedge was formally identical to the speculation discussed above, and required the same symbolic infrastructure. The spot market portion of a hedge, though, required classifications to act in a different semiotic capacity. Since these trades involved producers and consumers of agricultural goods, the content of classifications was paramount. The grading system had to provide a fair recompense to farmers based on the quality of their product and an accurate guide to manufacturers, who required their raw materials to meet certain physical standards. If grades did not accurately index these physical dimensions, the spot market component of the hedge would be unsatisfactory. Hedging thus required a classification system that, in addition to producing viable symbols, produced signs indexed to the physical qualities of commodities, i.e., an indexical infrastructure.

For indexical infrastructures, issues of practice-i.e., how grading was accomplished and integrated into the market — were critical. Indexical infrastructures straddled the messy, 
heterogeneous, world of material things and the homogeneous world of categories, classes and standards. The particular ways in which the former was made into the latter impacted the fidelity of the index produced. On CBOT, a succession of single parties, each with its own economic and political motives, produced grades that failed to index the physical qualities of wheat. This low fidelity for spot market purposes likely drove hedging to other exchanges with stronger indexical infrastructures. On NOCE, grading was negotiated by antagonistic parties, mediated by expert classers, and protected by Exchange supervision. These features guaranteed the high fidelity of grades as indexes in the spot market, making hedging safe for NOCE traders. ${ }^{13}$

The final type of trade — speculation in futures settled by delivery of spot commoditieswas both the least frequent and most complex. Whereas speculation and hedging involved transactions that took place entirely within either the spot or futures market, this type of trade involved movement across markets. It required an arrangement by which the grade qua symbol, which circulated in the futures market, could be linked with the grade qua index of the spot market. Building on Edwards's (2010) notion of 'gateways'—socio-technical devices that enable interoperation between otherwise incompatible systems - I conceive of these arrangements as 'semiotic gateways'.

The two exchanges created distinct semiotic gateways by which to mediate the translation from symbol to index. CBOT used warehouse receipts and the legal apparatus in which they were embedded. The warehouse receipt established what we might call 'indexicality by fiat': it automatically and permanently linked the grade as a symbolic entity and tool of speculation to the grade as an indexical guide to the commodity. Traders who needed to settle a contract through delivery could simply buy receipts for the proper grade of wheat, and rest assured that these would satisfy their obligations. On NOCE, the gateway was the intercession and judgment 
of expert cotton classers. This established a system of ‘indexicality by negotiation’: grades in their symbolic capacity had to be continuously re-linked to their indexical function. Traders forced to settle a speculative position through delivery needed to hire expert cotton classers to negotiate on their behalf in spot market transactions.

This difference shaped traders' orientation to settling contracts through the delivery of goods, and thus the volatility of the market. On NOCE, speculators faced a potentially substantial cost to settling by delivery. First; they had the additional cost of hiring expert cotton classers; second, they risked losing money on the deal due to adverse changes in grade from one transaction to another. Speculators were wary of these risks and costs, and would attempt to rid themselves of any contract they suspected might require delivery, even to the point of selling at below market price (Garside 1935). The cost of maintaining 'indexicality by negotiation' thus placed a check on speculation in the futures market. CBOT's system of 'indexicality by fiat' removed this brake. Warehouse receipts served to isolate speculators on the futures market from any cost related to handling and classifying wheat, even on the occasions when they were forced to deliver. Speculators could be confident that they could, quickly and at no extra cost, secure warehouse receipts which would satisfy their contracts. Through the mechanism of the warehouse receipt, CBOT supported a higher level of speculation than NOCE, with an accordingly higher risk of corners.

The differences in the semiotic character of grades produced on CBOT and NOCE thus promoted contrasting behaviors on their derivative markets. I argue that this difference contributed to the discrepancy in market volatility seen in the exchanges' formative years (see Figures $1 \& 2$ ). The low spot market fidelity of CBOT's grade made hedging difficult, while the permanent relation between its symbolic and indexical functions enabled unfettered speculation. 
NOCE's grade, by contrast, had high spot market fidelity, allowing for safe hedging, and an uncertain, costly method of linking symbolic and indexical functions, which tamped down speculation. In total, the argument traces the impact of classifications' semiotic qualities through to their market-level outcomes.

\section{Conclusion}

This article has outlined an approach to understanding classifications as semiotic entities. As opposed to the prevailing ontological method, a semiotic approach focuses on the possibilities opened up to market actors through the meanings classifications convey. This enables an analysis of how the fidelity of grades can shape market-level outcomes. It is thus through their semiotic properties, rather than any durable mechanistic features, that infrastructures can be seen to nondeterministically influence system-level outcomes.

My case specifically studies the semiotic impact of classifications on markets, but theory suggests that the analysis can be applied more broadly. The focus could be broadened from classifications to include other infrastructural components. These include standards (Aspers 2008; Lampland \& Star 2009), trading platforms (Knorr-Cetina \& Grimpe 2008), computer and communication networks (Edwards 2010), financial technologies (Kyrtis 2010; Pardo-Guerra 2013), social practices (Anand 2011; Elyachar 2010), and material devices (Poon 2009; Preda 2006). The breadth of infrastructure suggests a proliferation of semiotic entities within the market, whose nature and interaction remain to be discovered. Do all infrastructures communicate as classifications do? With what degree of specificity and with what scope? What relation exists among the semiotic character of multiple infrastructural components? Economic 
anthropologists have developed intriguing theories of the 'poetics' of infrastructure, suggesting that meaning may play a sizeable role in the functioning of many types of infrastructure (Larkin 2013; Mains 2012). The role of meaning among these varied infrastructures is a rich area for study.

Second, the focus of study could be shifted from markets to other organizations embedded within an infrastructure, such as firms or government agencies. Can a semiotic approach help us to understand systemic dynamics and outcomes in these environments as well? There are, of course, extensive literatures studying these organizations in non-semiotic ways: How might a semiotic approach engage with these? The multiple communities connected through a single infrastructure also directly points to the question of communication. What differences exist in the semiotic needs for infrastructural elements across communities? What impact do these differences have on communication and coordination? These questions further interrogate the nature of infrastructure as a foundational tool for communication.

The research presented in this article is only a first step toward addressing the broader issue of how infrastructures influence the systemic dynamics of the environments they underlie. I argue that considering the semiotic nature of infrastructure is a useful strategy for this broader project. It is a way of accounting for the continuing effects of infrastructures on the social environments they underlie and support, without reducing behavior to a mechanistic response to these systems. In this way, it complements traditional sociological analyses rooted in institutions, networks, and culture, and serves to further integrate materialist and culturalist explanations of social action. 


\section{Acknowledgements}

I would like to thank Akos Rona-Tas, Juan Pablo Pardo-Guerra, and Martha Lampland for their guidance and insight on this article and the dissertation of which it is a part, as well as the editors and two anonymous reviewers for their helpful comments.

David Pinzur is a graduate student in sociology at the University of California - San Diego. His dissertation research is on the creation of futures markets in post-bellum Chicago and New

Orleans.

\section{Notes}

1 Futures are a simple type of derivative. They are contracts that bind a buyer and seller to trade a particular class of commodity at a designated price at some specified future date. The price agreed to in a futures contract is thus a function of the underlying entity's current price and anticipated future fluctuations.

2 I use the terms 'classification' and 'grade' interchangeably in reference to my cases. But this equivalence should be understood as particular to these instances. Since 'grade' implies a scale while 'classification' does not, the two terms are not interchangeable in all circumstances. For this reason, in theoretical contexts, I use the more inclusive 'classifications'. 3 Icons signify through their resemblance to their object (e.g., a picture of a cigarette with a slash through it indicating, 'No Smoking'); indexes signify through pointing to their object (e.g., dark clouds and strong winds as a sign of impending rain); symbols signify through their connection to other symbols and their associations (e.g. words, which are meaningful primarily through their connection with other words in a language). Any sign can signify in any combination of one or all of these modes.

4 The notion of fidelity is prefigured by Muniesa, who argues that signs 'work well' when they signify 'unanimously and durably, at least to a certain degree and for a certain public' (2007: 387).

5 CBOT did briefly institute such a rule in October, 1868, but it was widely ignored by members, unenforced by the directorate, and repealed within months (Lurie 1979).

6 The study ends in 1909, a year when a number of transformative changes began on both exchanges. First, in this year, NOCE made a significant change to their grading system, implementing a centralized agency for grading contract cotton. Then, beginning in 1915, both exchanges experienced brief shutdowns and extensive price controls imposed by the federal government in response to World War I. Following the war, the federal government took control of the grading process, passing the Cotton Futures Act in 1916 and the Futures Trading Act of 1921. Because of these significant and rapid changes after 1909, I end my research at that point to maintain a general level of continuity over the course of the study.

7 In the first case, the Iowa Company's elevator burned to the ground and an examination of the remains revealed the shortage in grain compared to receipts. In the second, Munn \& Scott elevators went bankrupt and in the sale of their holdings to Armour \& Co., the shortfall of wheat in store had to be revealed (Taylor 1917). 
8 The amount of this premium or discount was determined at the close of every trading day by NOCE's Committee on Classification and Quotations.

9 Classers used multiple senses to judge the quality of cotton, visually inspecting the purity of lint and color, feeling for slight differences in body, and listening for the "cry" of the cotton as it was separated to judge staple length and strength of the fiber. Cotton classing was thought of by many as an art requiring incredible sensitivity and dexterity. As one merchant claimed: 'The hands of a cotton classer should be as soft as a debutante's and as supple as a violinist's' (Garside 1935: 77).

10 Corners were disruptive, but entirely legal, price manipulations that relied on letting traders build up large speculative positions in the futures market, then forcing them to settle in actual commodities-i.e., forcing a shift from treating classifications as symbols to treating them as indexes. In a corner, trader A would buy futures contracts from a number of different parties. He would simultaneously buy up the supply of the actual commodity promised in the contract. When the contracts came due, he would demand they be settled by delivery, at which point his counter-parties would find that Trader A, himself, was one of the only available sellers. Trader A would then sell his goods to the desperate, cornered parties at a highly inflated price, making a handsome profit.

11 This argument is, of necessity, theoretical. No permanent record of trades was kept, making it impossible to empirically determine what percentage of trades were made as hedges versus speculation.

12 This was a way of simplifying the multi-part transaction that would otherwise take place. The multi-part transaction is this: Trader A would buy receipts in the proper quality and amount at the current spot market price, say $\$ 1$ per bushel; he would then sell these receipts to Trader B at the price pre-arranged in their contract, say \$1.02 per bushel; Trader B would then sell these receipts on the spot market to Trader C, earning himself $\$ .02$ per bushel on the deal. Settling by difference collapsed these three transactions involving wheat to one transaction involving only cash: Trader A pays Trader B $\$ .02$ for every bushel contracted for in the futures contract. Both traders have the same losses and gains they would have in the multi-part transaction.

13 Though not featured in either of these case, iconic infrastructures also exist. The clearest example of an iconic infrastructure is a field guide, a pictorial system for classifying species of birds or plants. Iconic infrastructures are unique among the three types in that their status as infra-structural is most likely to fluctuate. While in routine cases of classification these icons are used passively as a background guide for everyday practice, they are also actively reference in more difficult cases: birders carry field guides in their packs and refer to them when they spot an unfamiliar species. Iconic infrastructures thus move fluidly between being infrastructures that invisibly support tasks and being highly visible tools. 


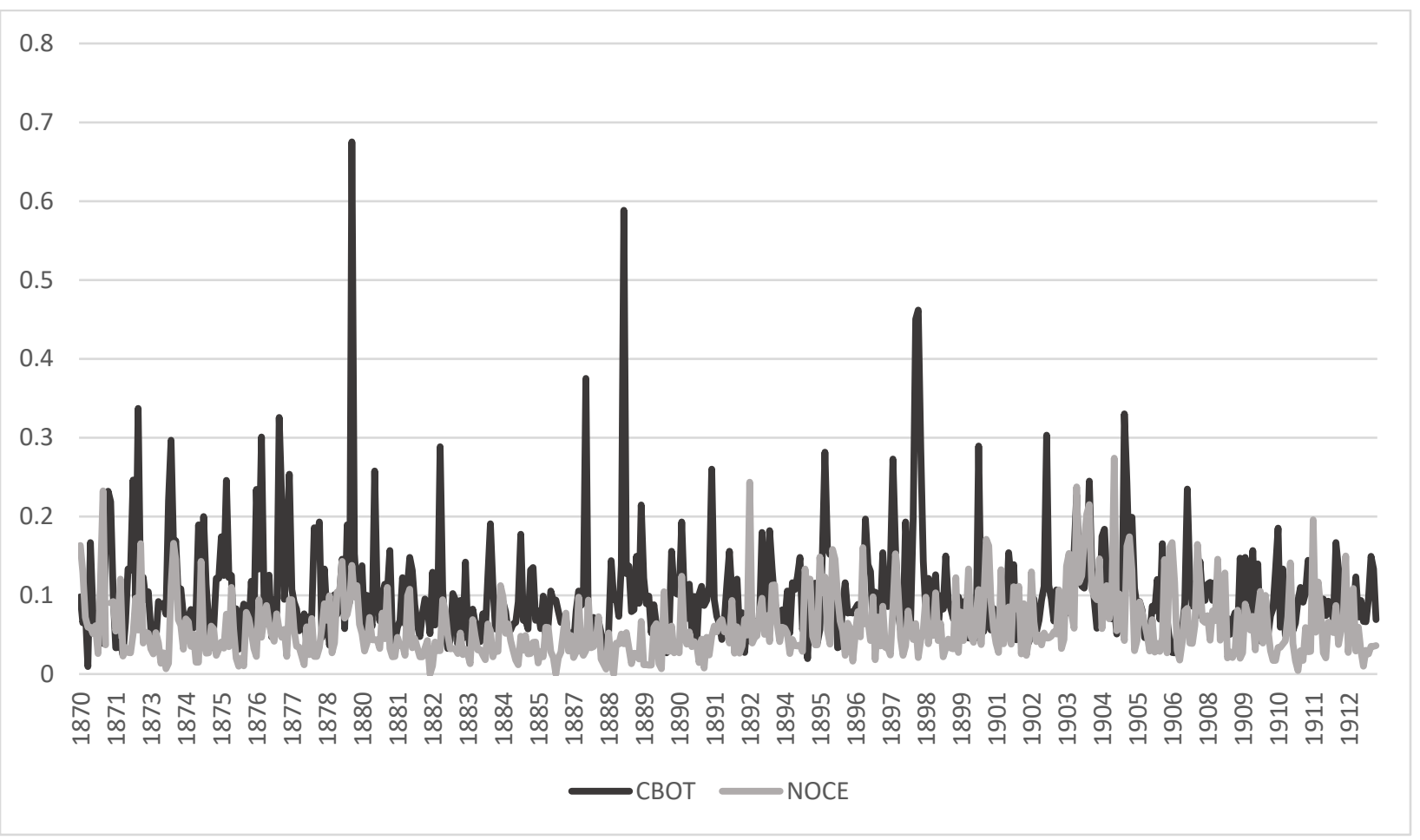

Figure 1 Intra-month commodity price volatility, September 1870 - August 1913. Volatility is calculated as the difference between monthly high and low prices divided by the average of the two. In mathematical terms, $\mathrm{V}=$ (Monthly high - monthly low $) /[($ Monthly high + monthly low)/2].

Source: Monthly high and low price data for the most commonly traded grades of wheat on CBOT and cotton on NOCE from Boyle (1922) and Boyle (1934). 


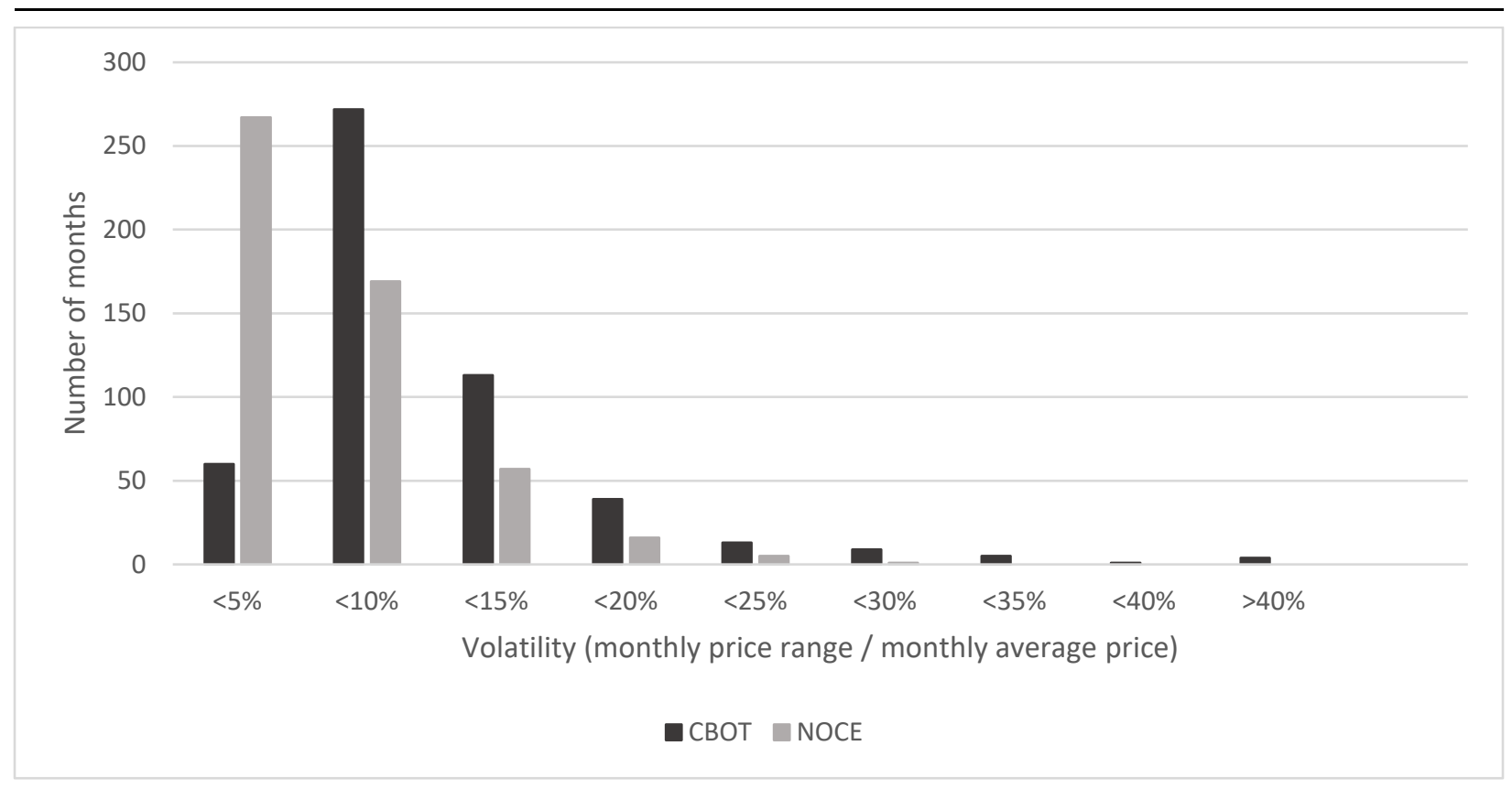

Figure 2 Intra-month price volatility, total months $(\mathrm{N}=516)$. Volatility is calculated as the difference between monthly high and low prices divided by the average of the two. In mathematical terms, $\mathrm{V}=($ Monthly high - monthly low $) /[($ Monthly high + monthly low $) / 2]$.

Source: Monthly high and low price data for the most commonly traded grades of wheat on CBOT and cotton on NOCE from Boyle (1922) and Boyle (1934). 


\begin{tabular}{|ll|}
\hline \multicolumn{1}{|c|}{ CBOT } & \multicolumn{1}{c|}{ NOCE } \\
$\begin{array}{l}\text { Wheat graded as it enters into } \\
\text { store }\end{array}$ & $\begin{array}{l}\text { Cotton graded at point of } \\
\text { exchange }\end{array}$ \\
$\begin{array}{l}\text { Grading done by independent, } \\
\text { single party }\end{array}$ & $\begin{array}{l}\text { Grade negotiated between } \\
\text { antagonistic parties }\end{array}$ \\
Grades materialized in receipts & $\begin{array}{l}\text { Grade exists only as } \\
\text { temporary agreement }\end{array}$ \\
\hline
\end{tabular}

Table 1 Implementation of grading infrastructure 


\section{References}

New Orleans Cotton Exchange records, Manuscripts Collection 652, Louisiana Research Collection, Howard-Tilton Memorial Library, Tulane University, New Orleans, LA 70118.

Chicago Board of Trade collection, Special Collections \& University Archives, University of Illinois at Chicago Library, Chicago, IL 60607.

Abolafia, M. (1996) Making Markets: Opportunism and Restraint on Wall Street, Cambridge, MA: London.

Anand, N. (2011) 'Pressure: the politechnics of water supply in Mumbai', Cultural Anthropology 26(4): 542-564.

Arnoldi, J. (2006). Frames and screens: the reduction of uncertainty in electronic derivatives trading. Economy and Society, 35(3): 381-399.

Baker, W. E. (1984) 'The social structure of a national securities market', American Journal of Sociology, 89(4), 775-811.

Barnes, B. (1983) 'Social life as bootstrapped induction', Sociology 17(4): 524-545.

Barry, A. (2001) Political Machines: Governing a Technological Society, London, UK: The Athlone Press.

Beunza, D., Hardie, I., and MacKenzie, D. (2006) 'A price is a social thing: towards a material sociology of arbitrage', Organization Studies 27 (5): 721-45.

Beunza, D. and Garud, R. (2007) 'Calculators, lemmings or frame-makers? The intermediary role of securities analysts', The Sociological Review 55: 13-39.

Beunza, D. and Stark, D. (2004) 'Tools of the trade: the socio-technology of arbitrage in a Wall Street trading room', Industrial and Corporate Change 13 (2): 369-400.

Biggart, N.W. (2001) 'Banking on each other: the situational logic of rotating savings and credit associations', Advances in Qualitative Organization Research 3: 129-53.

Bijker, W.E., Hughes, T.P. and Pinch, T.J. (1987) The Social Construction of Technological Systems: New Directions in the Sociology and History of Technology, Cambridge, MA: MIT Press.

Bloor, D. (1997) Wittgenstein, Rules and Institutions, New York: Routledge Press.

Bouilly, R. (1975) 'The Development of American Cotton Exchanges, 1870-1916', (Unpublished doctoral dissertation). University of Missouri, Columbia, MO.

Bowker, G. and Star, S. (2000) Sorting Things out: Classification and Its Consequences, Cambridge, MA: MIT Press.

Bowker, G. (1994) 'Information mythology and infrastructure', in L. Bud-Frierman (ed.) Information Acumen: The Understanding and Use of Knowledge in Modern Business, London, UK: Routledge.

Boyle, J. (1922) Chicago Wheat Prices for Eighty-One Years: Daily, Monthly and Yearly Fluctuations and Their Causes, Ithaca, NY: Cornell University Press.

Boyle, J. (1934) Cotton and the New Orleans Cotton Exchange: A Century of Commercial Evolution, Garden City, NY: Country Life Press.

Burt, R. (1992) Structural Holes: The Social Structure of Competition. Harvard University Press. 
Cronon, W. (1992) Nature's Metropolis: Chicago and the Great West, New York: WW Norton \& Company.

DeGoede, M. (2005) Virtue, Fortune, and Faith: A Genealogy of Finance. Minneapolis, MN: University of Minnesota Press.

Edwards, P. (2010) A Vast Machine: Computer Models, Climate Data, and the Politics of Global Warming, Cambridge: MIT Press.

Edwards, P.N., Bowker, G.C., Jackson, S.J., and Williams, R. (2009) 'Introduction: an agenda for infrastructure studies', Journal of the Association for Information Systems, 10(5): 364374.

Elyachar, J. (2010) 'Phatic labor, infrastructure, and the question of empowerment in Cairo', American Ethnologist, 37(3): 452-464.

Epstein, S. (2009) 'Beyond the standard human?', in Lampland, M. and Star, S. (eds) Standards and Their Stories: How Quantifying, Classifying, and Formalizing Practices Shape Everyday Life, Ithaca, NY: Cornell University Press.

Espeland, W.N. and Sauder, M. (2007). 'Rankings and reactivity: how public measures recreate social worlds', American Journal of Sociology 113(1): 1-40.

Espeland, W.N., and Stevens, M.L. (1998) 'Commensuration as a social process', Annual Review of Sociology, 313-43.

Fabian, A. (1990) Card Sharps, Dream Books, and Bucket Shops: Gambling in $19^{\text {th }}$-century America, Ithaca, NY: Cornell University Press.

Ferris, W. (1988) The Grain Traders, East Lansing: Michigan State University Press.

Foucault, M. (1982) The Archaeology of Knowledge, New York: Pantheon Books.

Fourcade, M. and Healy, K. (2013) 'Classification situations: life-chances in the neoliberal era', Accounting, Organizations and Society 38 (8): 559-72.

Garcia-Parpet, M-F. (2007) 'The Social Construction of a Perfect Market: The Strawberry Auction at Fontaines-En-Sologne', in D. MacKenzie, F. Muniesa and L. Siu (eds) Do Economists Make Markets, Princeton, NJ: Princeton University Press.

Garside, A. (1935) Cotton Goes to Market: a Graphic Description of a Great Industry, New York: Frederick A. Stokes Co.

Goldstein, B. (1928) Marketing: A Farmer's Problem, New York: Macmillan.

Greif, A. (1989) 'Reputation and coalitions in medieval trade: evidence on the Maghribi traders.' The Journal of Economic History, 49 (4): 857-882.

Gross, N. (2009) 'A pragmatist theory of social mechanisms." American Sociological Review, 74 (3): 358-79.

Hatherley, D., Leung, D. and MacKenzie, D. (2008) 'The finitist accountant: classifications, rules and the construction of profits', in Pinch, T. and Swedberg, R. (eds) Living in a Material World, Cambridge, MA: MIT Press.

Hughes, T.P. (1987) 'The evolution of large technological systems', in W.E Bijker, T.P. Hughes, and T.J. Pinch (eds) The Social Construction of Technological Systems: New Directions in the Sociology and History of Technology, Cambridge, MA: MIT Press.

Knorr Cetina, K. (2003) 'From pipes to scopes: the flow architecture of financial markets', Distinktion: Scandinavian Journal of Social Theory 4 (2): 7-23.

Knorr Cetina, K. and Grimpe, B. 'Global financial technologies: scoping systems that raise the world', in Pinch, T.J. and Swedberg, R. (eds) Living in a Material World, Cambridge, MA: MIT Press. 
Kyrtsis, A.A. Financial Markets and Organizational Technologies: System Architectures, Practices and Risks in the Era of Deregulation, New York: Palgrave Macmillan.

Lampland, M. (2010) 'False numbers as formalizing practices', Social Studies of Science 40 (3): 377-404.

Lampland, M. and Star, S. 2009. Standards and Their Stories: How Quantifying, Classifying, and Formalizing Practices Shape Everyday Life, Ithaca, NY: Cornell University Press.

Larkin, B. (2013) 'The politics and poetics of infrastructure', Annual Review of Anthropology, 42: 327-343.

Lea, T. and Pholeros, P. (2010) 'This is not a pipe: the treacheries of indigenous housing', Public Culture 22(1): 187-209.

Lee, G. (1938) 'History of the Chicago Grain Elevator Industry, 1840-1890', (Unpublished doctoral dissertation). Harvard University, Cambridge, MA.

Lurie, J. (1979) The Chicago Board of Trade, 1859-1905: The Dynamics of Self-Regulation, Chicago: University of Illinois Press.

MacKenzie, D. (2007) 'The material production of virtuality: innovation, cultural geography and facticity in derivatives markets', Economy and Society, 36(3), 355-376.

MacKenzie, D. and Millo, Y. (2003) 'Constructing a market, performing theory: the historical sociology of a financial derivatives exchange', American Journal of Sociology 109 (1): $107-45$.

Mains, D. (2012) 'Blackouts and progress: privatization, infrastructure, and a developmentalist state in Jimma, Ethiopia', Cultural Anthropology 27(1): 3-27.

Markham, J. 2002. A Financial History of the United States: From Christopher Columbus to the Robber Barons (1492-1900), Armonk, NY: ME Sharpe.

Maurer, B. (2002) 'Repressed futures: financial derivatives' theological unconscious', Economy and Society, 31(1), 15-36.

Meyer, J.W., and Rowan, B. (1977) 'Institutionalized organizations: formal structure as myth and ceremony', American Journal of Sociology, 340-63.

Millerand, F. and Bowker, G. (2009) 'Metadata standards: trajectories and enactment in the life on an ontology', in Lampland, M. and Star, L. (eds) Standards and Their Stories: How Quantifying, Classifying, and Formalizing Practices Shape Everyday Life, Ithaca, NY: Cornell University Press.

Miller, P. and O'Leary, T. (1987) 'Accounting and the construction of the governable person', Accounting, Organizations and Society 12 (3): 235-65.

Miller, P., and Rose, N. (1990) 'Governing economic life', Economy and Society 19 (1): 1-31.

Millo, Y. (2007) 'Making things deliverable: the origins of index-based derivatives', in Callon, M., Millo, Y. and Muniesa, F. (eds) Market Devices, Oxford, UK: Blackwell Publishing

Muniesa, F. (2007) 'Market technologies and the pragmatics of prices', Economy and Society 36 (3): 377-95.

Pardo-Guerra, J-P. (2010) 'Creating flows of interpersonal bits: the automation of the London Stock Exchange, c. 1955-90.” Economy and Society 39 (1): 84-109.

Pardo-Guerra, J-P. (2013) 'Making markets: infrastructures, engineers and the moral technologies of finance', (unpublished paper), London School of Economics and Political Science, London.

Pinch, T. and Swedberg, R. (eds) (2008). Living in a Material World: Economic Sociology Meets Science and Technology Studies, Boston, MA: MIT Press. 
Poon, M. (2009) 'From New Deal institutions to capital markets: commercial consumer risk scores and the making of subprime mortgage finance." Accounting, Organizations and Society 34 (5): 654-74.

Preda, A. (2006) 'Socio-technical agency in financial markets', Social Studies of Science 36 (5): $753-82$.

Preda, A. (2009) Framing Finance: The Boundaries of Markets and Modern Capitalism, Chicago: University of Chicago Press.

Pryke, M., \& Allen, J. (2000) 'Monetized time-space: derivatives-money's "new imaginary"'? Economy and Society, 29(2), 264-284.

Rauch, J.E. and Casella, A. (2001) Networks and Markets, New York: Russell Sage Foundation.

Rona-Tas, A. (2014) 'The off-label use of consumer credit ratings', Paper presented at the Annual Conference of the Society for the Advancement of Socio-Economics, Chicago, IL.

Santos, J. (2002) 'Did futures markets stabilise US grain prices?' Journal of Agricultural Economics 53 (1): 25-36.

Sherman, A. (1934) The History of the New Orleans Cotton Exchange, 1871-1914, (Unpublished masters thesis). Tulane University, New Orleans, LA.

Smith, C. (2011) 'Coping with contingencies in equity option markets: the "rationality" of pricing', in Beckert, J. and Aspers, P. (eds) The Worth of Goods, Oxford, UK: Oxford University Press.

Star, S. (2002) 'Infrastructure and ethnographic practice', Scandinavian Journal of Information Systems, 14(2): 107-122.

Star, S. and Griesemer, J. (1989) 'Institutional ecology, translations and boundary objects: amateurs and professionals in Berkeley's Museum of Vertebrate Zoology, 1907-39', Social Studies of Science 19 (3): 387-420.

Star, S. and Ruhleder, K. (1996) 'Steps toward an ecology of infrastructure: design and access for large information spaces." Information Systems Research 7 (1): 111-34.

Stark, D. (2009) The Sense of Dissonance: Accounts of Worth in Economic Life, Princeton, NJ: Princeton University Press.

Taylor, C. (1917) History of the Board of Trade of the City of Chicago, Chicago: RO Law.

United States Congress House Committee on Agriculture. (1892) Testimony Taken Before the Committee on Agriculture During a Consideration of Bills Nos. 392, 2699, and 3870, Restricting and Taxing Dealers in "futures" and "options" in Agricultural Products, and for Other Purposes. Washington, DC: U.S. Government Printing Office.

Williamson, O.E. (1981) 'The economics of organization: the transaction cost approach', American Journal of Sociology, 548-577.

Wittgenstein, L. (1967) Philosophical Investigations, New York: Blackwell.

Wright, E.O., Levine, A., and Sober, E. (1992) Reconstructing Marxism: Essays on Explanation and the Theory of History, London: Verso.

Zaloom, C. (2004) 'Time, space, and technology in financial networks', in Castells, M (ed.) The Network Society: A Cross-cultural Perspective, Northampton, MA: Edgar Elgar Publishing, Inc.

Zaloom, C. (2006) Out of the Pits: Traders and Technology from Chicago to London, Chicago: University of Chicago Press. 